JRSSEM 2021, Vol. 01, No. 4, 439 - 446

E-ISSN: 2807 - 6311, P-ISSN: 2807 - 6494

\title{
IMPLEMENTATION OF SUSTAINABLE FINANGE AND ENVIRONMENT
}

\author{
Winona Bianda Callista ${ }^{1^{*}}$ \\ Choirul Anwar ${ }^{2}$ \\ Hafifah Nasution ${ }^{3}$ \\ 1,2,3 Accountancy Department, State University of Jakarta, Indonesia \\ e-mail: winonabiandacallista@gmail.com¹, choirul_anwar@unj.ac.id², \\ hafifah.nasution@unj.ac.id ${ }^{3}$ \\ *Correspondence: winonabiandacallista@gmail.com
}

Submitted: 1 November 2021, Revised: 10 November 2021, Accepted: 14 November 2021

\begin{abstract}
This study aims to determine management's perception of strategy in implementing sustainable finance and environment in related companies. This study uses primary data with phenomenological research methods obtained through interviews, documentation, and analysis of the content of sustainability reports to obtain more detailed information. The subject of this research is the management of a construction company in Indonesia. The result of this research is the implementation to achieve sustainable finance is by budgeting for investment by considering environmental, social, and governance factors. Implementation of sustainable finance as a component of green finance that aims to support balanced economic growth. The implementation of a sustainable environment along with the company's social aspects is summarized in the $\mathrm{K} 3 \mathrm{~L}$ (Health, Occupational Safety, and Environment) policy. The company also has a special budget for sustainability programs and strategies on social and environmental issues.
\end{abstract}

Keywords: management; sustainability reporting; sustainable finance; sustainable environment; manager's perception. 


\section{INTRODUCTION}

Problems regarding the financial, environmental and social aspects of the company are not enough if they are only presented in the company's financial statements. According to (Tjandra, 2021), the financial statements presented by the company are no longer seen as sufficient as a reference for information in making decision making. The information in the financial statements is seen as very limited and unable to provide a sufficient picture in seeing the company's prospects in the future. Business continuity is not only seen from the profits at the time the financial statements are published, but also from the various efforts made by the company in establishing good cooperation with various existing stakeholders. Therefore, a report that describes the company from various perspectives other than financial statements is increasingly needed (Siregar, Prayoga, \& Sudarmaji, 2019). The report in question is a sustainability report or sustainability report.

According to (Otoritas Jasa Keuangan, 2017), a sustainability report is a form of report carried out by companies in order to disclose or provide information to all stakeholders related to the performance of Environmental, Social, and Good Governance (LST) in an accountable manner. To support the company's sustainability, it is necessary to implement sustainable finance that refers to OJK Regulation No. 51/ POJK 03/2017 concerning the Implementation of Sustainable Finance for Financial Services Institutions, Issuers, and Public Companies. In implementing the OJK mandate, companies must prepare work priorities and strategies to achieve sustainability. Finance (sustainable finance) is part of a sustainability report which is the financial industry practices that promote sustainable growth by aligning economic, social, and environmental (Otoritas Jasa Keuangan, 2017).

The magnitude of the role of disclosure of additional company information such as sustainability reports is as one of the company's communication media with stakeholders. Although the types of disclosure in Indonesia are increasingly diverse, from internet media, websites company, social media, financial reports, and profiling company, sustainability report has own added value, because it describes the company's concern and predicts how the company will be in the future (Aldi \& Djakman, 2020). By publishing a sustainability report, the company has also shown its seriousness in maintaining environmental balance and sustainability, minimizing social inequality, and economic prosperity.

The concept of corporate sustainability refers to the ability of a company to use its limited resources effectively and efficiently over time where waste of resources can be reduced and this practice is implemented properly (Shad et al., 2019). The previous research conducted by Faroog \& de Villiers (2019) aims to explore how sustainability reporting managers institutionalize sustainability reporting in organizations. The result of the study states that managers play a key role with the Key Performance Index (KPI) which describes the company's effectiveness in achieving business goals, which is integrated with planning, 
performance measurement, and risk management processes in order to institutionalize sustainability reporting within the organization by carrying out institutional work. It can be categorized into four stages. Each stage takes into various approaches that organizations adopt to prepare corporate sustainability reports (including how they conduct materiality assessments and stakeholder engagement).

In implementing sustainability, the performance of the 3-P pillars or triple bottom line, namely Profit (economic aspect), People (social aspect), and Planet (environmental aspect) must work in harmony. Refers to the economic aspect of the 3-P, namely economic prosperity by generating profits, achieving competitive advantage and sustaining the overall economic value of the business. In the 3-P environmental aspect, environmental sustainability includes factors related to environmental quality such as climate change, global warming, pollution, and depletion of the ozone layer. While the 3-P social aspect includes issues related to social progress such as health, safety, welfare, job opportunities, charity, and organizational behavior (Aras et al., 2018).

For companies that focus on sustainability, they need to ensure that their business can manage business risks and meet stakeholder expectations. Companies or organizations that seek to conduct business while being socially and environmentally responsible should try to place the dominant sustainability management framework in predicting organizational performance (Maletič et al., 2018). So this analysis is to assess and see the suitability of the implementation of the sustainability report made by the company based on the company's real activities. This research briefly intend to get to know the strategies which is planned by the managers as key role and identify the sustainable implementation within finance and environmental matter.

\section{METHODS}

The approach used in this study is a qualitative phenomenological approach. Phenomenology is an approach that was started by Edmund Hussert in 1920 and developed by Martin Heidegger in 1927 to understand or study the experience of human life (Zahavi, 2018). Phenomenology is an approach that focuses more on the concept of a particular phenomenon and the form of its study is to see and understand the meaning of an experience related to a particular phenomenon (Helaluddin, 2018). The general focus of this research is to examine or examine the essence or structure of experience into human consciousness and is associated with the phenomena that occur (Tuffour, 2017). To strengthen the phenomenological qualitative approach, this study uses primary data obtained from interviews with the company's management to obtain managers' perceptions, documentation of sustainability reports regarding things needed in this research, including the economic aspects of the company to see the implementation of sustainable finance and environmental aspects to assess the extent to which the company that is the subject of research implements a 
sustainable environment in order to achieve sustainable development, the company's sustainability report is obtained from the official website of the company concerned. The reason for choosing informants, namely managers, is because they are part of the support for making sustainability reports because managers act as agents as has been determined in agency theory, so that the performance and thoughts of managers are crucial to achieve sustainable development (Rudyanto \& Siregar, 2018). Managers who were used as informants for this study were financial accounting managers and QHSE (Quality, Health Safety, and Environment) managers because they were directly related to financial and environmental sustainability, which were the subject of this research. Data analysis techniques used in this research are data reduction, data presentation, and content analysis.

\section{RESULTS AND DISCUSSION}

Sustainable growth results from the alignment between the interests of economic, social, and environmental performance. To support the economic performance of the company, it is necessary to implement sustainable finance. The definition of sustainable finance in Indonesia is defined as the company's overall support for sustainable growth resulting from the alignment of economic, social and environmental interests. According to (Otoritas Jasa Keuangan, 2017), the implementation of sustainable finance has the aim of increasing the company's resilience and competitiveness so that it is able to grow and develop sustainably, providing funding sources needed by the community referring to the Long-Term Development Plan (RPJP) and Medium-Term Development Plan (RPJM) which are characterized by 3Ps. , as well as contributing to the national commitment to global warming through business activities that are prevention/mitigation as well as adaptation to climate change towards a competitive low-carbon economy. The goal is to improve the quality of the company so that it can grow and develop stably and for long term.

The implementation of sustainable finance certainly has several general functions, namely reducing social inequality, reducing and preventing environmental damage, maintaining biodiversity, and encouraging efficient use of energy and natural resources. Since the regulation regarding the implementation of sustainable finance for Financial Service Institutions, Issuers, and Public Companies was issued by (Otoritas Jasa Keuangan, 2017), namely POJK Number 51/POJK.03/2017, the companies studied have implemented sustainable finance in sustainability reports after the regulation was published until now. The implementation of sustainable finance is actually a development of the concept of sustainability that has been carried out by the company before, namely the triple bottom line or 3P (profit, people, and planet). The goal is to improve the quality of the company so that it can grow and develop stably and in the long term.

Based on the results of interviews with the company's accounting and finance managers, sustainable finance is the 
company's implementation to keep financial statements running according to existing regulations, starting with keeping the reports transparent, accountable, and presented in accordance with the Statement of Financial Accounting Standards (PSAK). Because this company is a public company, reporting must be informed openly and as widely as possible to both the public and the government. Furthermore, the principles of Good Corporate Governance (GCG) must be applied in funding activities, from the most basic through the application of the company's vision and mission in every company activity to social responsibility (Soelton et al., 2020). In addition, the company must also manage cash flow well and be able to contribute to stakeholders, cash flow management is one of the key components of the company's financial stability. The benefits of cash management are that it makes it easier for companies to carry out various business transactions as well as monitoring the transactions carried out, minimizing the possibility of risks that may occur in each transaction, and all financial transactions can be structured and controlled (Santioso et al., 2021).

Furthermore, for the company's sustainability implementation for environmental aspects, one of them is by having and implementing $\mathrm{K} 3 \mathrm{~L}$ (Health, Occupational Safety, and Environment) policies. The policy implies a commitment to assisting the community in finding answers to all problems related to meeting the needs of the community in the area around the company's project operations and future generations. It aims to create independence and quality of life for the community. By continuing to apply high standards of safety, occupational safety, environment, and public health as well as establishing partnerships with the government and local communities, the company is simultaneously trying and creating sustainable development in the economic, environmental and social fields in the long term (Caesaria \& Basuki, 2017).

In carrying out business activities, the company makes efforts to preserve the environment and empower the community's capabilities. The commitment to preserving the environment is realized through the provision of a special budget for financing various environmental conservation programs and activities. In addition, the company also carries out energy savings, water management, emission control, waste management (B3 and non-B3), implementing Go Green Construction, restoration and protection of habitats (Aniela, 2012).

The company's efforts to save energy are by making efficient use of electrical energy, replacing fuel oil with gas fuel, and utilizing solar panels to generate electricity which is then used as lighting. Water management is carried out by the company by utilizing and optimizing efforts to maintain the availability of water sources. For the process of working on projects that require water, land for projects in the regions and using PDAM for projects in urban areas. Water intake and utilization is carried out with regular supervision. Furthermore, to be able to control emissions, what the company does is to plant trambesi trees which are very useful for absorbing carbon gas emissions and carry out regular emission measurements, 
either directly or indirectly. Meanwhile, waste management is regulated according to the type of waste generated. There are three types of waste produced by this company, namely non-B3 liquid waste which will be channeled into city drainage channels, non-B3 solid waste which will be separated according to the type between organic and inorganic which will then be submitted to the local Sanitation Service and for metal waste will be submitted to special collectors of metal waste and B3 waste which will be handled by storing them in special containers or drums equipped with symbols and tables before being temporarily stored and then handed over to collectors who have permits. For the project concept with a green perspective, the company always pays attention to Environmental Impact Analysis (AMDAL) in every project implementation. In Government Regulation No. 27 of 1999 concerning Environmental Impact Analysis, it is stated that AMDAL is a study about major and important impacts for decisionmaking of planned business or activity on the environment that is required for the decision-making process regarding the implementation of the business. AMDAL is a study of both the positive and negative impacts of planned activity or project, which is used by the government in deciding whether an activity or project is environmentally appropriate or not and AMDAL as a scientific analysis, regarding predictions on the environment as stated by (Laia, 2021). The positive and negative impact studies are usually prepared by considering the physical, chemical, biological, socio-economic, socioeconomic, socio-cultural, and public health aspects.

And for the last point, namely habitat restoration and protection, the company carries out environmental conservation on barren land, reforestation or replanting, adds water catchment areas, and opens green space for the surrounding environment.

\section{CONCLUSIONS}

To achieve sustainable growth, the company implements sustainable finance that can improve the quality of the company so that it can grow and develop stably in the long term. The company has implemented sustainable finance since the OJK regulations were issued and is still ongoing today. What is being done for sustainable finance is to maintain financial reports so that they are always transparent, accountable, presented in accordance with PSAK, as well as budgeting costs for sustainability programs that will balance economic, environmental and social aspects. In addition, the principles of GCG must be applied in funding activities, cash flow management must also be carried out by the company, and be able to make a positive contribution to stakeholders.

\section{REFERENCES}

Aldi, B., \& Djakman, C. D. (2020). Persepsi Manajemen dan Stakeholders pada Pencapaian Sustainable Development Goals (SDGs) dalam Sustainability Reporting. Jurnal Riset Akuntansi Dan Keuangan, 8(2), 405-430.

Aniela, Y. (2012). Peran Akuntansi Lingkungan Dalam Meningkatkan 
Kinerja Lingkungan Dan Kinerja Keuangan

Perusahaan. Berkala Ilmiah Mahasiswa Akuntansi, 1(1).

Aras, G., Tezcan, N., \& Furtuna, O. K. (2018). Multidimensional comprehensive corporate sustainability performance evaluation model: Evidence from an emerging market banking sector. Journal of Cleaner Production, 185, 600609.

Caesaria, A. F., \& Basuki, B. (2017). The study of sustainability report disclosure aspects and their impact on the companies' performance. SHS Web of Conferences, 34, 8001.

Farooq, M. B., \& de Villiers, C. (2019). Understanding how managers institutionalise sustainability reporting: Evidence from Australia and New Zealand. Accounting, Auditing and Accountability Journal, 32(5), 1240-1269. https://doi.org/10.1108/AA AJ-06-2017-2958

Helaluddin, H. (2018). Mengenal lebih dekat dengan pendekatan fenomenologi: sebuah penelitian kualitatif. Jurnal ResearchGate.

Laia, F. (2021). Pertanggungjawaban Pidana Terhadap Tindak Pidana Pencemaran Lingkungan Hidup. Jurnal Indonesia Sosial Sains, 2(4), 524-534.

Maletič, M., Maletič, D., \& Gomišček, B. (2018). The role of contingency factors on the relationship between sustainability practices and organizational performance. Journal of Cleaner Production, 171, 423-433.

Otoritas Jasa Keuangan. (2017). Infografis Lembaga Jasa Keuangan dan Emiten Penerbit Sustainability Report. Otoritas
Jasa Keuangan.

https://www.ojk.go.id/sustainable-

finance/id/publikasi/riset-dan-

statistik/Pages/Sustainability-Report-

bagi-Lembaga-Jasa-Keuangan-dan-

Emiten.aspx

Rudyanto, A., \& Siregar, S. V. (2018). The effect of stakeholder pressure and corporate governance on the sustainability report quality. International Journal of Ethics and Systems.

Shad, M. K., Lai, F.-W., Fatt, C. L., Klemeš, J. J., \& Bokhari, A. (2019). Integrating sustainability reporting into enterprise risk management and its relationship with business performance: A conceptual framework. Journal of Cleaner Production, 208, 415-425.

Siregar, Amelia Oktrivina, Prayoga, M. Adam, \& Sudarmaji, Eka. (2019). Fraud of Financial Statements in Diamond Theory's Perspective: Empirical Study of Transportation Sub Sector Companies in The Indonesia Stock Exchange. The International Journal of Business Review (The Jobs Review), 2(1), 63-74.

Soelton, M., Ramli, Y., Anggraini, D., \& Khosasi, D. (2020). Implementing good corporate governance to engage corporate social responsibility in financial performance.

Tjandra, L. (2021). Potensi penerbitan laporan keberlanjutan menggunakan GRI STANDARDS dan prediksi rating pada PT YAMAZAKI INDONESIA (MY ROTI). Universitas Pelita Harapan.

Tuffour, I. (2017). A critical overview of interpretative phenomenological analysis: A contemporary qualitative research approach. Journal of 
Healthcare Communications, 2(4), 52.

Zahavi, D. (2018). Phenomenology the basics. Routledge.

(c) (7) (2) (C) 2021 by the authors. Submitted

EY SA for possible open accesspublication

under the terms and conditions of the Creative Commons Attribution (CC BY SA) license (https://creativecommons.org/licenses/by-sa/4.0/). 